\title{
CERAPAN MAHASISWA PROGRAM STUDI PENDIDIKAN SENI RUPA UNIVERSITAS NEGERI MAKASSAR TERHADAP SENSASI RUANG PADA KARYA SENI LUKIS MODERN NONREPRESENTATIF
}

\author{
Sukarman B., Agussalim Djirong \\ Fakultas Seni dan Desain Universitas Negeri Makassar \\ sukarmanb@unm.ac.id \\ agussalim.djirong@unm.ac.id
}

\begin{abstract}
ABSTRAK
Penelitian ini berjudul " Cerapan Mahasiswa Program Studi Pendidikan Seni Rupa Universitas Negeri Makassar terhadap Sensasi Ruang pada Karya Seni Lukis Modern Nonrepresentatif'. Penelitian ini Pemikiran dilatarbelakangi berkembangnya karya seni lukis modern nonrepresentatif yang jauh dari representasi keadaan alam, yang sering membuat publik kesulitan untuk menikmatinya, terutama oleh publik awam, meskipun karya-karya tersebut tergolong karya seni bermutu. Fenomena ini juga terjadi di kalangan mahasiswa meskipun mereka telah dibekali banyak pengetahuan tentang seni lukis modern serta banyak melakukan aktivitas seni. Seni lukis modern nonrepresentatif dalam perkembangannya banyak menunjukkan pertimbangan ruang yang matang bersama unsur-unsur visual lainnya dalam mengeksplor kesan-kesan artistik. Masalah penelitian adalah "Bagaimanakah daya cerap mahasiswa Program Studi Pendidikan Seni Rupa Universitas Negeri Makassar terhadap sensasi ruang pada karya seni lukis modern”. Penelitian ini dilakukan dengan tujuan mengetahui dan menggambarkan kondisi riil daya cerap mahasiswa Program Studi Pendidikan Seni Rupa Universitas Negeri Makassar terhadap sensasi ruang pada karya seni, dan secara khusus terhadap karya seni lukis modern nonrepresentatif. Manfaat penelitian ini adalah (1) diperoleh informasi yang akurat mengenai kondisi nyata daya cerap mahasiswa Program Studi Pendidikan Seni Rupa Universitas Negeri Makassar terhadap sensasi ruang pada karya seni lukis modern nonrepresentatif, yang sekaligus menggambarkan daya cerap terhadap sensasi ruang pada karya seni secara umum; (2) memberikan gambaran keberhasilan pembelajaran yang dilakukan selama ini terhadap mahasiswa Program Studi Pendidikan Seni Rupa Universitas Negeri Makassar, terutama pembelajaran yang terkait, yang dapat dijadikan masukan untuk pengembangan sistem pembelajaran. Data dikumpulkan melalui tes apresiasi. kemudian diolah dan dianalisis dengan teknik persentase kemudian diinterpretasi secara kualitatif.
\end{abstract}

\section{ABSTRACT}

This study entitled "Student's perception of Arts Education Studies Program, State University of Makassar on Sensation space of the Nonrepresentative Modern Art Painting". This research is the development background of thinking of modern paintings nonrepresentative away from representation in natural conditions, which often makes it difficult to enjoy the public, especially by the lay public, although the works are considered works of art quality. This phenomenon also occurs among the students even though they have provided a wealth of knowledge about modern painting, and many art activities. Nonrepresentative modern painting in its development shows a lot of space considerations are ripe with other visual elements in exploring artistic impressions. Research problem is "How do students perceive the Arts Educational Studies Program, State University of Makassar to the sensation of space on the work of modern painting." This research was conducted with the aim to know and describe the real condition of the students perceive the Arts Educational Studies Program, State University of Makassar to the sensation of 
space in works of art, and in particular the works of nonrepresentative modern painting. The benefits of this research are (1) obtain accurate information about the real conditions of students perceive the Arts Educational Studies Program, State University of Makassar to the sensation of space on the work of nonrepresentative modern painting, which also describes the power to perceive the sensation of space in works of art in general; (2) provides a learning success of students carried out during this Arts Education Studies Program, State University of Makassar, especially related learning, which can be used as input for the development of learning systems. Data collected through appreciation test. then processed and analyzed with the techniques then interpreted qualitatively percentage.

\section{PENDAHULUAN}

Seni lukis modern dalam sejarah perkembangannya lahir berbagai gaya dan corak. Kelahiran berbagai gaya dan corak itu didorong antara lain oleh adanya ketidakpuasan terhadap gaya dan corak yang telah berkembang sebelumnya di samping munculnya konsepkonsep baru dalam memandang seni. Gaya dan corak seni lukis modern yang hadir tidak hanya yang sifatnya representatif, tetapi juga yang nonrepresentatif. Soedarso mengungkapkan bahwa, "memang seni modern tidak terbatas oleh hal-hal yang kasat mata seperti objek lukisan tertentu maupun corak dan gaya tertentu, melainkan ditentukan oleh sikap batin senimannya"(Soedarso, 2000: 3).

Seni lukis modern nonrepresentatif dalam perkembangannya banyak menunjukkan eksplorasi artistik melalui permainan ruang dalam mengorganisasikan unsur-unsur visual. Ekplorasi artistik melalui pengorganisasian ruang dalam seni lukis mulai ditunjukkan secara jelas oleh Piet Mondrian dalam karyanya, misalnya pada karya "Komposisi dengan Kuning" (Soedarso, 2000: 125). Semangat ini terus berlangsung dan memunculkan berbagai corak karya seni lukis nonrepresentatif yang menonjolkan permainan ruang hingga berpengaruh terhadap karya-karya seni lainnya.

Pada era dewasa ini, banyak seni lukis hadir tidak lagi mengemban makna lewat figurasi representatif, tetapi melalui bentukbentuk nonrepresentatif yang jauh dari reprepsentasi yang kasat mata, dengan sangat memperhitungkan pengaturan ruang untuk menampilkan kesan artistik. Bahkan, banyak seniman yang memang hanya mengekplorasi ruang dengan pengorganisasian unsur-unsur visual tanpa bermaksud menyampaikan pesan di luar estetika ruang itu sendiri. Oleh karena itu, untuk berhadapan dengan karya seperti itu dibutuhkan pengetahuan dan kepekaan terhadap fenomena ruang untuk bisa mencerap sensasi estetiknya.

Hadir dan berkembangnya karya seni lukis modern dengan gaya dan corak yang sangat beragam dewasa ini sering kali menyebabkan publik kesulitan untuk menikmatinya, terutama oleh publik awam, meskipun karya-karya tersebut sangat mungkin tergolong karya seni bermutu. Kesulitan menikmati terutama ditunjukkan terhadap karya-karya nonrepresentatif yang jauh dari representasi keadaan alam. Fenomena ini tidak jarang pula terjadi di kalangan mahasiswa program studi Pendidikan Seni Rupa. Banyak di antara mereka menunjukkan sikap acuh terhadap karya seni lukis modern nonreprensentatif yang bermutu meskipun mereka telah dibekali banyak pengetahuan tentang seni lukis modern serta telah banyak pula melakukan aktivitas seni. Fenomena itu diduga terjadi karena ketidakmampuan menangkap getaran-getaran estetik yang dipancarkan dari karya seni tersebut, dan hal itu tentulah merupakan ironi di tengah harapan datangnya apresiasi dari kalangan awam.

Kesenjangan yang digambarkan di atas menjadi alasan perlunya melakukan penelitian untuk mengetahui kemampuan apresiasi mahasiswa program studi Pendidikan Seni Rupa Universitas Negeri Makassar terhadap karya seni lukis modern 
nonrepresentatif, yang pada kesempatan ini difokuskan pada daya cerapnya terhadap sensasi ruang. Pemfokusan terhadap cerapan sensasi ruang dilakukan dengan pertimbangan semakin banyaknya karya seni lukis modern nonrepresentatif yang mengedepankan sensasi artistik melalui permainan ruang/bidang.

Penelitian ini secara umum bertujuan mengetahui dan menggambarkan kondisi riil daya cerap mahasiswa Program Studi Pendidikan Seni Rupa Universitas Negeri Makassar terhadap sensasi ruang pada karya seni, dan secara khusus terhadap karya seni lukis modern nonrepresentatif.

Seni secara umum diartikan "segala kegiatan dan hasil karya manusia yang mengutarakan pengalaman batinnya yang karena disajikan secara unik dan menarik memungkinkan timbulnya pengalaman atau kegiatan batin pula pada diri orang lain yang menghayatinya" (Soedarso, 2000: 2). Seni lukis adalah salah satu bidang seni yang memanfaatkan unsurunsur rupa (garis, bentuk, warna, tekstur, dan ruang) dalam pengutaraan pengalaman batin. Menurut Sofyan Salam "istilah seni lukis mengacu pada karya seni yang dihasilkan melalui goresan-goresan warna yang relatif lebar melalui sapuan kuas, palet" (Salam, 2001: 4). Namun demikian, seni lukis dalam perkembangannya dapat ditemukan tidak menggunakan warna (hitam-putih) serta tidak dengan sapuan kuas atau palet.

Istilah "modern" dalam seni diartikan sebagai sesuatu yang baru atau belum pernah ada sebelumnya. Istilah "modern" dalam hal ini tidak selalu harus dihubungkan dengan waktu. Sarah Newmeyer dalam bukunya menulis bahwa, "seni modern itu boleh jadi berupa gambar bison yang digoreskan 20.000 tahun yang lalu dan boleh jadi juga karya Picasso yang baru saja diselesaikan pagi ini" (Soedarso, 2000: 2). Pendapat ini jelas menunjukkan bahwa ia menggunakan istilah modern tidak dalam hubungannya dengan kronologi, melainkan dimaksudkan untuk menamai suatu kelompok karya yang memiliki sifat-sifat tertentu. Sifat tertentu yang dimaksud adalah menampilkan sesuatu yang baru yang belum pernah ada sebelumnya (kreatif).
Konsep "modern" secara khusus dalam seni rupa sangat jelas dapat dipahami dari ungkapan Sofyan Salam yang menyatakan, "seni rupa modern adalah seni rupa yang berpijak pada pandangan modernisme yang memuja kebebasan individual, kebaruan, dan perkembangan" (Salam, 2000: 2). Dengan demikian, "seni lukis modern" yang merupakan salah satu kelompok karya seni lukis dapat pula diartikan seni lukis yang berpijak pada pandangan modernisme yang memuja kebebasan individual, kebaruan, dan perkembangan.

Dalam sejarah perkembangannya, karya seni lukis modern dapat digolongkan berdasarkan coraknya. Corak itu dibentuk oleh faham yang melandasinya, di antaranya: Realisme, Naturalisme, Impresionisme, Fauvisme, Ekpressionisme, Kubisme, Abstrakisme, Dadaisme, Surrealisme, dan Pop Art. Seni lukis realis berupaya menggambarkan kenyataan sesuai keadaan sesungguhnya. Pemilihan objek lebih diarahkan pada suasana kehidupan yang meperihatinkan atau mengerikan. Sebaliknya, seni lukis naturalis melukiskan keadaan alam dengan kecenderungan menampilkan objek yang indah, bahkan memperindah objek. Seni lukis impressionis cenderung menegaskan penangkapan kesan cahaya pada objek. Seni lukis faufis terasa sangat bebas dalam mengekplorasi bentuk maupun warna objek yang digambarkan. Walaupun Faufisme belum memperkenalkan bentuk-bentuk abstrak, tetapi tanda-tanda untuk sampai ke situ sudah ada. Seni lukis ekspressionis adalah berusaha melukiskan aktualitas yang sudah didistorsikan ke arah suasana seperti kesedihan, kekerasan, ataupun tekanan batin yang berat. Seni lukis kubistis memiliki konsepsi sendiri mengenai bentuk dan ruang, dan anggapannya terhadap objek sebagai motif-motif geometris abstrak. Dengan konsep itu, seni lukis kubistis menggambarkan objeknya dalam beberapa sisi dengan bentuk bersegi-segi (kubistis). Seni lukis abstrak yaitu kelompok karya seni lukis yang lebih menonjolkan susunan garis, bentuk, dan warna yang sama sekali terbatas dari ilusi atas bentuk-bentuk di alam. Secara umum seni 


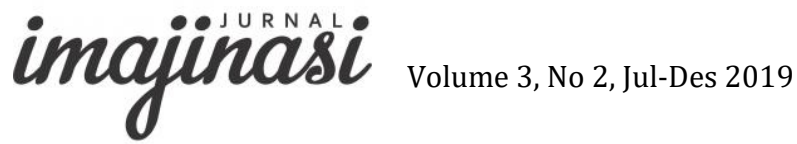

lukis abstrak tidak lagi memfungsikan bentukbentuk alam sebagai objek ataupun tema yang harus dibawakan, melainkan sekadar motif saja (jika ada) sebagai dalih untuk membuat sesuatu. Karya seni lukis seperti inilah yang di dalam penelitian ini digolongkan sebagai seni lukis nonrepresentatif.

Seni lukis modern nonrepresentatif yaitu karya seni lukis yang dihasilkan dengan prinsip modernisme, yang tidak dimaksudkan untuk mereprentasikan bentuk-bentuk yang ada di alam. Seni lukis jenis ini biasa pula disebut seni lukis abstrak. Seni lukis abstrak dapat dibedakan atas dua macam, yaitu abstrak ekpresi dan abstrak komposisi.

Abstrak ekspresi yaitu karya seni lukis abstrak yang mengedepankan spontanitas dalam pengungkapan imajinasi sang pelukisnya. Bentuk abstrak yang ditampilkan lahir secara spontan dari imajinasi yang terkesan begitu bebas saat menggoreskan warna pada bidang lukisnya. Proses menuangkan warna secara spontan menjadi aspek penting bagi sang pelukis. Salah satu tokohnya yang sangat terkenal dalam dunia seni rupa adalah Jacson Pollock. Boleh dikatakan Pollock merupakah tokoh perintis seni lukis abstrak bercorak ekpresionis. Contoh karya Jackson Pollock bercorak abstrak ekspresionis dapat dilihat pada gambar berikut.

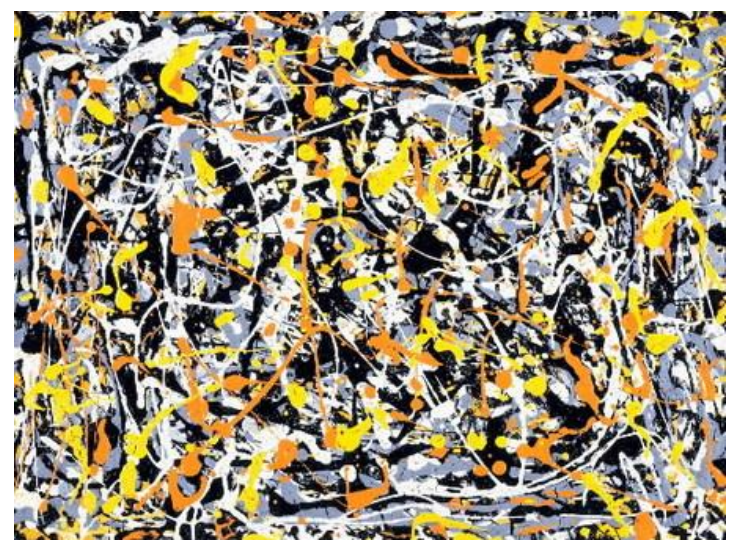

Gambar 1

Contoh seni lukis abstrak ekpresionis karya Jacson Pollock
Karya-karya seni lukis abstrak bercorak ekspresionis yang muncul kemudian semakin berkembang. Beberapa karakter dari corak ekspresionis juga tampak dalam perkembangannya disebakan oleh teknik dan media yang digunakan pelukisnya. Dua buah contoh karya seni lukis abstrak bercorak ekspresionis yang memperlihatkan karakteritik yang berbeda ditampilkan berikut ini untuk memperjelas corak ekspresionis yang dimaksud.
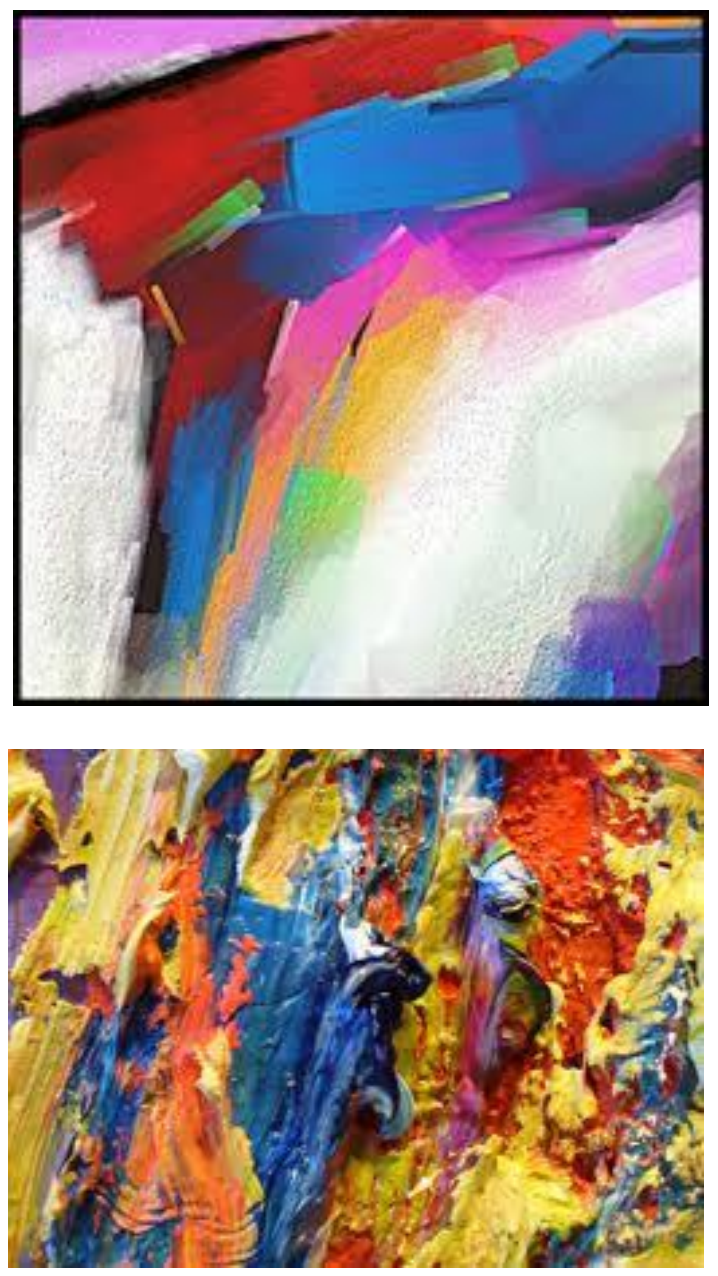

Gambar 2

Contoh seni lukis abstrak ekpresionis (Anonim

Abstrak komposisi yaitu jenis karya seni lukis abstrak yang mengedepankan permainan 
ruang/bidang melalui pengorganisasian bentukbentuk dan warna. Konsep ruang/bidang terasa sangat kental mendasari seni lukis abstrak bercorak komposisionis ini. Tokohnya yang sangat terkenal dalam dunia seni rupa adalah Piet Modrian dengan corak karyanya yang sangat khas seperti gambar berikut.

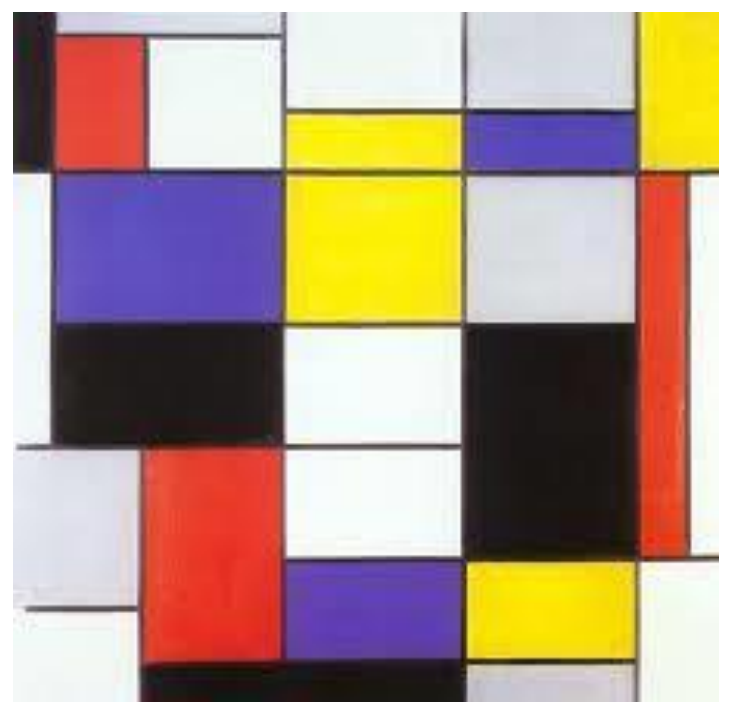

Gambar 3

Contoh seni lukis abstrak komposisionis karya Piet Mondrian

Seperti halnya corak ekspresionis, karya seni lukis abstrak bercorak komposisionis yang muncul kemudian juga semakin berkembang. Beberapa karakter dari corak komposisionis juga tampak dalam perkembangannya terutama disebakan oleh konsep ruang dianut pelukisnya. Untuk lebih menegaskan pemahaman terhadap corak karya seni lukis abstrak komposisionis, ditampilkan tiga buah contoh karya seperti gambar berikut ini.4a.

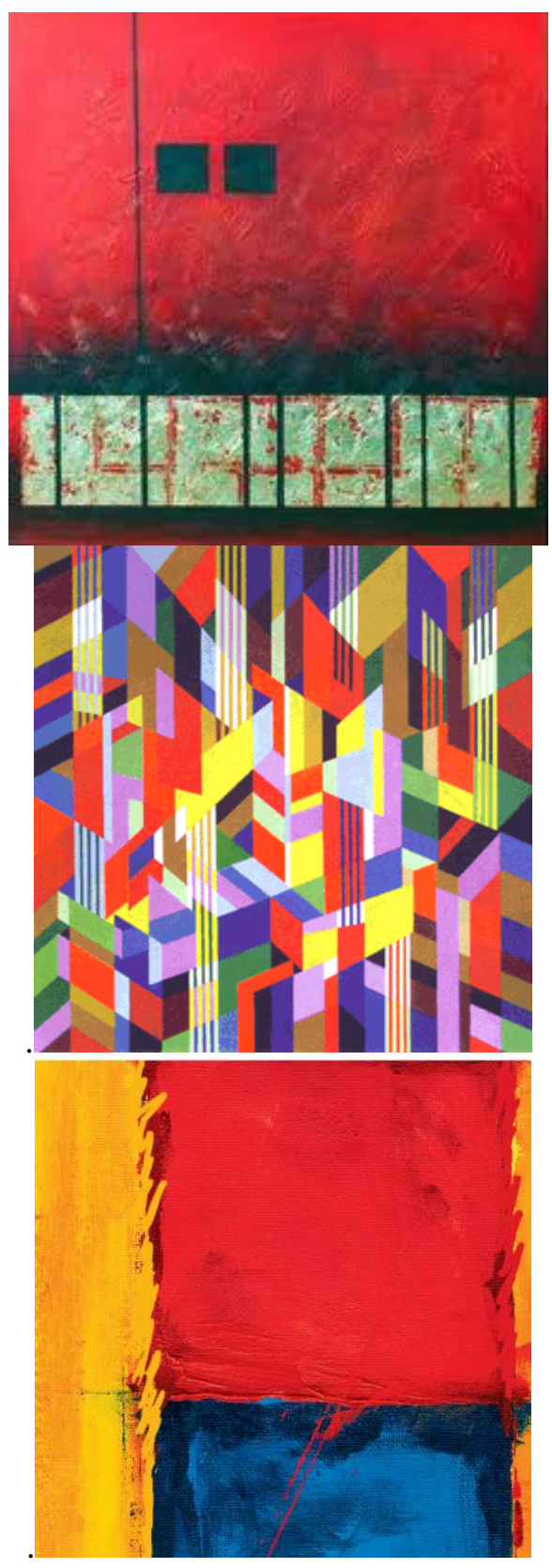

Gambar 4

Contoh seni lukis abstrak komposisionis (Anonim

\section{Unsur-Unsur Seni Lukis}

\section{Garis (Line)}

Ada beberapa pengertian garis. Ada yang mengatakan garis adalah dua buah atau lebih titik yang bersambung. Garis adalah goresan yang memiliki panjang. Garis adalah batas atau 
limit suatu bidang. Beberapa contoh garis, sebagai berikut.

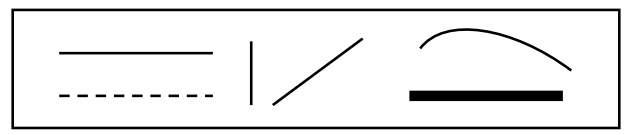

Gambar 5

Beberapa contoh jenis garis)

\section{Bentuk (Shape)}

Wucius Wong (1986: hal 4) mengatakan semua unsur tersusun dalam sesuatu yang disebut bentuk, yaitu raut yang memiliki ukuran, warna, dan barik tertentu. Wucius Wong menggolongkan bentuk dapat berupa titik, garis, dan bidang. Secara umum bentuk bidang dapat digolongkan atas bentuk-bentuk geometris dan bentuk-bentuk organis, seperti pada gambar berikut.

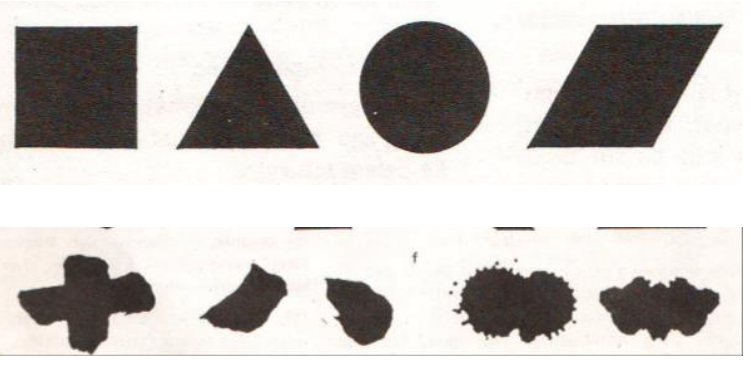

Gambar 6

Bentuk-bentuk geometris

Bentuk-bentuk organis

\section{Warna (Color)}

Warna dapat dipahami melalui dua bidang ilmu, yaitu ilmu fisika dan ilmu bahan. Menurut ilmu fisika, warna adalah kesan yang ditimbulkan oleh cahaya pada mata. Menurut ilmu bahan, warna adalah semacam zat berupa pigmen (dalam bahasa Inggeris, pigmen = zat warna)

Warna memiliki peran sangat penting dalam kehidupan manusia. Di dalam kehidupan seharihari, warna mempunyai meberapa peran, di antaranya:

1. Warna mewakili alam
Warna dapat berperan mewakili alam terutama untuk menggabarkan objek alam, seperti pohon dengan warna hijau untuk daunnya dan coklat untuk batangnya, langit dengan warna biru, matahari dengan warna merah atau jingga.

2. Warna sebagai simbol

Warna berperan sebagai simbol apabila digunakan untuk melambangkan sifatsiat tertentu. Contoh praktis pada penggunaan warna merah dan putih pada bendera kebangsaan RI, merah menyimbolkan berani dan putih menyombolkan suci. Beberapa jenis warna dan sifat-sifat yang biasa disimbolkannya dapat dilihat di bawah ini.

3. Warna mewakili dirinya

Warna mewakili dirinya sendiri bila dipergunakan sekadar menampilkan warna itu, tidak untuk melambangkan sesuatu, atau dengan kata lain ia tampil otonom. Contoh penggunaan warna yang mewakili dirinya sendiri adalah warna benda yang dimiliki, misalnya rumah, kendaraan, dsb.

\section{Tekstur (Texture)}

Tektur ialah sifat khas atau karakter permukaan suatu bentuk atau raut. Setiap raut memiliki permukaan dan setiap permukaan memiliki sifat khasnya, licin atau kasar, polos atau bercorak, kusam atau sega, lunak atau keras.

\section{Ruang (Space)}

Ruang dalam hal ini identik dengan bidang, yaitu permukaan yang panjang dan lebar. Menurut kamus, Ruang ialah (1) sela-sela antara dua (deret) atau empat tiang; (2) rongga yang tebatas atau yang lingkung oleh bidang; (3) rongga yang tidak terbatas atau tempat segala yang ada. Menurut Plato, ruang adalah sesuatu yang terlihat dan teraba, menjadi teraba karena memiliki karakter yang jelas berbeda dengan semua unsur lainnya. Menurut Leibniz, 
"ruang adalah sesuatu yang diakibatkan oleh hubungan antar obyek". Menurut Kant, "ruang adalah konsep sistematis yang sebenarnya diciptakan dalam pikiran kita untuk menjelaskan persepsi yang diterima akibat sensasi panca indera dengan hal-hal lain yang berhubungan dengan kita sebagai subyek" (astudioarchitect.com, 2009).

Belvin (1980) membedakan ruang antara ruang nyata (actual space) dan ruang gambar (pictorial space). Ruang nyata ruang tampak secara visual, dapat dirasakan dan diraba. Ruang nyata dapat berwujud dua dimensi atau tiga dimensional. Ruang gambar adalah ruang yang digambarkan, yang sifatnya tidak nyata (semu). Ruang ini dikatakan semu karena hanya dipersepsikan berdasarkan penglihatan.

\section{Sensasi Ruang pada Karya Seni Lukis}

Manusia dalam kehidupannya selalu berada di suatu ruang dan selalu berhubungan dengan ruang. Di dalam kehidupan, manusia senantiasa berinteraksi, berintegrasi, bahkan menyatukan dirinya dengan ruang, baik hal itu disadari maupun tidak. Suatu ruang bagi manusia bisa menjadi sesuatu yang menyenangkan dan menenangkan, sebaliknya dapat pula menjadi sesuatu yang menggerahkan dan menggelisahkan. Bagi orang yang menyadari hubungan suatu ruang dengan dirinya biasanya dapat menyiasati ruang tersebut menjadi sesuatu yang menyenangkan bahkan mungkin bermakna bagi dirinya. Di dalam kesadaran seperti itulah, para pekerja seni atau artis bermain menyiasati ruang hingga mampu memberi sensasi artistik terhadap karya-karyanya.

Sensasi menurut pengertian kamus adalah "sesuatu yang membuat perasaan terharu, rusuh, gempar, merangsang, dsb.". Bila istilah sensasi ini dikaitkan dengan kata ruang maka dapat diartikan rasa terharu, rusuh, gempar, atau terangsang yang ditimbulkan oleh ruang. Pengertian ini memberi pemahaman bahwa tentunya rasa itu muncul pada seseorang bila ia dapat menagkap getaran-getaran artistik dari ruang itu, dan hal ini sangat ditentukan oleh tingkat kepekaan seseorang.
Pada karya seni lukis, permainan ruang sangat mungkin menimbulkan sensasi bila ruang tersebut diorganisasikan bersamaan dengan warna dan bentuk oleh seniman yang memiliki konsep ruang yang matang dan kepekaan pengkomposisian yang tinggi. Contoh karya seni lukis yang memiliki sifat itu dapat dilihat pada contoh-contoh karya seni lukis abstrak bercorak komposisionis (gambar 3 dan 4).

\section{METODE PENELITIAN}

Variabel yang menjadi fokus kajian dalam penelitian ini, yakni "cerapan terhadap sensasi ruang" secara operasional secara operasional didefinisikan sebagai: Kemampuan menangkap rangsangan estetik dari pengorganisasian unsur ruang pada karya seni lukis, yang ditunjukkan melalui tanggapan dan atau jawaban terhadap sejumlah pertanyaan tertulis berkaitan dengan sensasi ruang karya seni lukis nonrepresentatif yang diajukan oleh peneliti.

Populasi penelitian ini adalah mahasiswa program studi pendidikan seni rupa yang masih aktif pada tahun akademik yang sedang berjalan (2010/2011), yang jumlahnya sebanyak 850 orang. Populasi tersebut kemudian disampel dengan menggunakan teknik purpossive sampling, yakni memilih mahasiswa program studi pendidikan seni rupa yang berada pada sesemester $\mathrm{V}$ dengan pertimbangan bahwa, masiswa pada semester itu dipandang telah memperoleh banyak pengetahuan serta pengalaman tentang peran dan pengorganisasian ruang pada karya seni rupa dibandingkan dengan mahasiswa berada pada semester di bawahnya. Selain itu, mahasiswa pada semester $\mathrm{V}$ pada umumnya masih aktif ke kampus untuk mengikuti perkuliahan sehingga relatif mudah diorganisasikan untuk diteliti dibandingkan mahasiswa yang berada pada semester di atasnya.

Pengambilan data dalam penelitian ini dilakukan dengan menggunakan tes. Jenis tes yang digunakan adalah tes apresiasi yang secara khusus dirancang untuk mengetahui tingkat cerapan mahasiswa terhadap sensasi ruang pada karya seni lukis modern nonrepresentatif. Tes ini tidak mengukur tingkat kebenaran jawaban 
imajinasisi

Volume 3, No 2, Jul-Des 2019 yang diberikan responden atas pertanyaan yang diajukan. Melainkan hanya melihat daya cerapnya terhadap sensasi ruang pada karya, yang ditunjukkan pada jawaban yang diberikan. Dalam proses pengembangan tes, peneliti memilih sejumlah karya seni lukis modern nonrepresentatif dari berbagai sumber, yang unsur permainan ruangnya untuk menggugah kepekaan estetik terasa sangat menonjol. Untuk menetapkan karya yang akan dijadikan bahan tes, peneliti berkonsultasi dengan beberapa orang pakar yang dipandang berkompeten untuk memberikan pertimbangan dan masukan dalam pengembangan tes tersebut.

Tes yang digunakan mengajukan sepuluh item pertanyaan yang berupanya mendeteksi daya cerapan mahasiswa terhadap sensasi ruang yang ada pada karya seni lukis modern nonrepresentatif.

Data yang diperoleh dalam penelitian ini berupa hasil tes apresiasi yang menunjukkan tingkat kepekaan terhadap sensasi ruang. Data tersebut diolah melalui proses skoring terhadap setiap jawaban yang diberikan oleh responden. Skoring dilakukan berdasarkan tingkat pencerapan responden yang diketahui melalui sejumlah pertanyaan tertulis yang disertai dengan gambar karya seni lukis yang menjadi rujukan. Skor yang diberikan terhadap setiap jawaban menggunakan rentangan 0-10. Setelah jawaban terhadap sepuluh item pertanyaan selesai diskor, selanjutnya ditotal untuk mendapatkan skor akhir setiap responden. Selanjutnya, skor responden ditabulasi untuk melihat frekuensi pada setiap interval skor. Interval skor yang digunakan mengikuti sistem penilaian di perguruan tinggi, yakni 0-100 yang dibagi menjadi lima kategori sebagai brikut:
1. $91-=$ Sangat tinggi
100
2. $76-=$ Tinggi
90
3. $61-=$ Sedang 75
4. $51-=$ Rendah
60
5. $\leq 50=$ Sangat rendah

Hasil tabulasi frekuensi berdasarkan interval di atas kemudian diinterpretasi secara kualitatif.

\section{PEMBAHASAN}

Perolehan skor atas jawaban terhadap tes no.1 menunjukkan bahwa hanya $4(22,22 \%)$ dari 18 orang responden memperoleh skor pada rentangan 9,1-10 dan sebanyak 14 orang $(77,78 \%)$ responden yang memperoleh skor pada rentangan 5,0 ke bawah. Ini berarti bahwa responden yang memberikan jawaban atas pertanyaan tes no.1, yang menunjukkan indikasi bahwa responden tersebut mencerap sensasi ruang pada empat karya yang ditunjukkan, jumlahnya sangat kecil. Sebaliknya jumlah responden yang memberikan jawaban yang tidak menunjukkan indikasi mencerap sensasi ruang sangat besar. Data ini dapat dimaknai bahwa berdasarkan berdasarkan pesentase itu, sebagian besar responden belum mampu mencerap sensasi ruang pada karya seni lukis modern. Pada umumnya responden dalam merespon karya masih lebih terkonsentrasi mencerap bentuk dan warna. Aspek pembagian ruang yang juga menimbulkan sensasi belum mendapat perhatian.

Perolehan skor atas jawaban terhadap tes no.2 yang sifatnya meminta responden menelaah secara langsung sebuah karya untuk mengetahui daya cerapnya terhadap karya seni lukis modern nonrepresentatif menunjukkan bahwa ada $9(50 \%)$ dari 18 orang responden yang memperoleh skor pada rentangan 9,1-10 dan sebanyak 9 orang $(50 \%)$ responden yang memperoleh skor pada rentangan 5,0 ke bawah. Ini berarti bahwa jumlah responden yang memberikan jawaban atas pertanyaan no.2 yang menunjukkan indikasi bahwa responden tersebut mencerap sensasi ruang pada karya yang ditunjukkan berimbang dengan jumlah responden yang memberi jawaban tidak menunjukkan indikasi mencerap sensasi ruang. Persentase responden yang mencerap sensasi ruang pada karya ini jauh lebih besar dari persentase responden yang mencerap sensasi 
ruang pada empat karya yang ditunjukkan pada tes no.1, meskipun karya yang ditunjukkan pada tes no.2 sama dengan salah satu karya yang ditunjukkan pada tes no.1.

Perolehan skor atas jawaban terhadap tes no. 3 seperti halnya tes no. 2 yang sifatnya meminta responden menelaah secara langsung sebuah karya untuk mengetahui daya cerapnya terhadap karya seni lukis modern nonrepresentatif menunjukkan bahwa ada 1 $(5,56 \%)$ dari 18 orang responden memperoleh skor pada rentangan $6,1-7,5$ dan 17 orang $(94,44 \%)$ responden memperoleh skor 5,0 ke bawah. Ini berarti bahwa jumlah responden yang memberikan jawaban atas pertanyaan no.3 yang menunjukkan indikasi bahwa responden tersebut mencerap sensasi ruang pada karya yang ditunjukkan sangat kecil dibandingkan dengan jumlah responden yang memberi jawaban menunjukkan indikasi tidak mencerap sensasi ruang. Indikasi yang ditunjukkan pada jawaban yang diberikan juga memiliki tingkat keyakinan berkategori sedang karena skornya berada pada rentangan 6,1-7,5.

Perolehan skor atas jawaban terhadap tes no.4 menunjukkan perolehan skor jawaban atas pertanyaan yang sifatnya meminta membandingkan enam buah karya untuk mengetahui daya cerap responden terhadap karya seni lukis modern nonrepresentatif menunjukkan bahwa ada $2(11,11 \%)$ dari 18 orang responden memperoleh skor pada rentangan 5,1-6,0 dan 16 orang $(88,89 \%)$ responden memperoleh skor 5 ke bawah. Ini berarti bahwa tidak ada responden yang memberikan jawaban atas pertanyaan no.4 yang menunjukkan indikasi bahwa responden tersebut mencerap sensasi ruang pada karya yang ditunjukkan. 2 orang $(11,11 \%)$ responden yang jawabannya memperoleh skor pada rentangan 5,1-6,0 dapat dikatakan berada pada tingkat keyakinan rendah, selebihnya berada pada tingkat keyakinan sangat rendah. Dengan demikian, berdasarkan skor atas jawaban yang diberikan reponden terhadap tes no.4 ini dapat dikatakan bahwa daya cerap responden terhadap sensasi ruang pada karya yang ditunjukkan sangat rendah.
Perolehan skor atas jawaban terhadap tes no.5 menunjukkan bahwa ada 7 (38,89\%) dari 18 orang responden memperoleh skor pada rentangan 9,1 - 10 dan 11 orang $(61,11 \%)$ responden memperoleh skor 5,0 ke bawah. Ini berarti bahwa jumlah responden yang memberikan jawaban atas pertanyaan no.5 yang menunjukkan indikasi bahwa responden tersebut mencerap sensasi ruang pada karya yang ditunjukkan jauh kecil dibandingkan dengan jumlah responden yang memberi jawaban menunjukkan indikasi tidak mencerap sensasi ruang. Hal serupa ditunjukkan pada perolehan skor atas jawaban terhadap tes no. 6, 7, dan 8. Perolehan skor atas jawaban terhadap tes no. 6 menunjukkan bahwa ada $3(16,67 \%)$ dari 18 orang responden memperoleh skor pada rentangan $9,1-10$ dan 15 orang $(83,33 \%)$ responden memperoleh skor 5,0 ke bawah. Perolehan skor atas jawaban terhadap tes no. 7 menunjukkan bahwa ada $7(38,89 \%)$ dari 18 orang responden memperoleh skor pada rentangan $9,1-10$ dan 11 orang $(61,11 \%)$ responden memperoleh skor 5,0 ke bawah. Perolehan skor atas jawaban terhadap tes no. 8 menunjukkan bahwa ada $8(44,44 \%)$ dari 18 orang responden memperoleh skor pada rentangan 9,1 - 10 dan 10 orang $(55,56 \%)$ responden memperoleh skor 5,0 ke bawah. Meskipun keempat tabel tersebut menunjukkan jumlah responden yang memberikan jawaban yang mengindikasikan mereka mencerap sensasi ruang pada karya yang ditunjukkan pada ketiga item tes (no 5, 6, 7, dan 8) sangat kecil, namun jumlah kecil itu memiliki tingkat keyakinan sangat tinggi karena berada pada rentangan skor 9,1-10.

Tes no. 9 dan 10 sifatnya membandingkan dua buah karya untuk mengetahui daya cerap responden terhadap karya seni lukis modern nonrepresentatif. Perolehan skor atas jawaban terhadap tes no.9 menunjukkan bahwa ada 5 $(27,78 \%)$ dari 18 orang responden memperoleh skor pada rentangan 9,1-10 dan 13 orang $(72,22 \%)$ responden memperoleh skor $5,0 \mathrm{ke}$ bawah. Tabel 10 menunjukkan ada $8(44,44 \%)$ dari 18 orang responden memperoleh skor pada rentangan $9,1-10$ dan 8 orang $(55,56 \%)$ responden memperoleh skor 5,0 ke bawah. 
Meskipun kedua tabel tersebut menunjukkan jumlah responden yang memberikan jawaban yang mengindikasikan mereka mencerap sensasi ruang pada karya yang ditunjukkan pada kedua item tes (no 9 dan 10) sangat kecil, namun jumlah kecil itu memiliki tingkat keyakinan sangat tinggi karena berada pada rentangan skor 9,1-10.

Tabulasi perolehan skor atas jawaban seluruh responden terhadap seluruh pertanyaan menunjukkan frekuensi pada setiap rentangan skor. Tabulasi tersebut menunjukkan bahwa ternyata setelah seluruh skor ditotalkan, tidak ada $(0 \%)$ responden yang memperoleh skor pada rentangan 91-100. Hanya 2 orang $(11,10 \%)$ yang memperoleh skor pada rentangan $76-90,1$ orang $(5,56 \%)$ yang memperoleh skor pada rentangan 61-75, dan 3 orang $(16,67 \%)$ yang memperoleh skor pada rentangan 51-60. Jumlah yang cukup besar yakni 12 orang $(66,67 \%)$ yang perolehan skornya berada pada rentangan 50 ke bawah.

Persentase yang digambarkan di atas menunjukkan tingkat cerapan responden secara umum terhadap sensasi ruang pada karya seni lukis modern nonrepresentatif. Atas dasar itu, dapat dinyatakan bahwa tidak ada $(0 \%)$ yang memiliki daya cerap sangat tinggi, 2 orang $(11,10 \%)$ yang memiliki daya cerap tinggi, 1 orang $(5,56 \%)$ yang memiliki daya cerap sedang, 3 orang $(16,67 \%)$ yang memiliki daya cerap rendah, dan 12 orang $(66,67 \%)$ yang memiliki daya cerap sangat rendah. Apabila dijumlahkan persentase yang berkategori rendah dan sangat rendah maka persentasenya sebesar $83,34 \%$. Hal ini berarti secara umum responden kurang memiliki daya cerap atau kurang responsif terhadap sensasi ruang yang ada pada karya seni lukis modern nonrepresentatif.

Perlu pula ditegaskan pada bahasan ini bahwa jawaban-jawaban responden yang dinilai mengindikasikaan adanya cerapan mereka terhadap aspek sensasi ruang kemudian dijadikan dasar dalam menarik kesimpulan diduga kurang menunjukkan tingkat keakuratan yang tinggi. Dugaan itu didasarkan pada terjadinya ketidakkonsistenan responden dalam memberikan jawaban terhadap pertanyaanpertanyaan serupa yang bermaksud melihat/mengukur daya cerapnya terhadap sensasi ruang melalui kekonsistenan jawabannya. Hal ini pula menjadi alasan perlunya pengembangan instrumen tes apresiasi lebih lanjut dan melakukan validasi untuk menghasilkan instrumen yang dapat memberikan data lebih akurat. Oleh karena itu, hasil penelitian ini dapat bahan sekaligus menjadi rekomendasi awal untuk melakukan penelitian pengembangan model tes apresiasi yang dapat menjadi protipe bagi yang ingin mengukur kemampuan apresiasi.

\section{KESIMPULAN DAN SARAN 4.1. Kesimpulan}

Berdasarkan data yang telah disajikan dan hasil pembahasan seperti yang telah diuraikan pada bab IV, dapat ditarik beberapa kesimpulan sebagai berikut:

1. Mahasiswa program studi Pendidikan Seni Rupa Universitas Negeri Makassar, lebih khusus yang berada pada semester lima memiliki daya cerap sangat rendah terhadap sensasi ruang pada karya seni lukis modern nonrepresentatif.

2. Mahasiswa tersebut pada umumnya masih lebih memberi perhatian pada aspek bentuk, warna, dan pemaknaan ketika sedang mengamati karya seni lukis modern nonrepresentatif. Dengan kata lain, aspek permainan ruang yang sesungguhnya berperan dalam menimbulkan sensasi artistik belum dapat dicerap.

3. Mahasiswa dalam memberikan jawaban atas pertanyaan yang bermaksud mengukur daya cerapnya terhadap sensasi ruang tidak konsisten sehingga responden yang berada dalam kategori memiliki daya cerap sedang dan tinggi terhadap sensasi ruang tersebut, yang 
jumlahnya sangat sedikit (hanya $16,66 \%$ ), belum terpercaya $100 \%$.

\subsection{Saran}

Berkenaan dengan hasil penelitian yang telah diperoleh, disarankan beberapa hal sebagai berikut:

1. Penyelenggaraan mata kuliah pada program studi Pendidikan Seni Rupa Universitas Negeri Makassar, khususnya yang memberi wawasan dan membangun kepekaan artistik dalam mengamati unsur-unsur visual dan aspek-aspek estetik karya seni, perlu memberi perhatian terhadap pengembangan kepekaan mahasiswa terhadap sensasi ruang. Hal itu dipandang perlu agar mahasiswa tersebut kelak tidak menunjukkan ironi karena ketiakmampuannya menangkap getaran-getaran artistik karya seni yang dipancarkan dari permainan ruangnya.

2. Penelitian serupa perlu lebih diintensifkan untuk menyediakan beragam rujukan model pengukuran kemampauan apresiasi bagi sivitas akademika, khususnya pada program studi Pendidikan Seni Rupa.

3. Perlu digiatkan penelitian pengembangan model tes apresiasi agar tersedia referensi yang memadai untuk melakukan pengukuran kemampuan apresiasi seni. Hal ini dipandang perlu mengingat adanya kendala yang dirasakan dalam penelitian ini dalam hal pengembangan tes karena terbatasnya model tes apresiasi yang baku, khususnya di lingkungan Universitas Negeri Makassar.

\section{DAFTAR PUSTAKA}

Bevlin, Majorie Elliot, 1980: Design Through Discovery, Holt, Rinegart and Winston, New York Chichago San Francisco Atlanta Dallas Montreal Toronto London Sydney.
Sobandi, Bandi, 2008: Model Pembelajaran Kritik dan Apresiasi Seni Rupa, Jurusan Pendidikan Seni Rupa FBSUPI,Dirjen Pendidikan Tinggi.

Soedarso SP, 1991: Beberapa Catatan tentang Perkembangan Kesenian Kita, BP ISI Yogyakarta.

Soedarso SP, 2000: Sejarah Perkembangan Seni Rupa Modern, CV. Studio Delapan Puluh Enterprice bekerja sama dengan Badan Penerbit ISI Yogyakarta, Jakarta.

Sofyan Salam, 2000: Seni Rupa Mimesis dan Modern/Kontemporer di Sulawesi Selatan (Sebuah Pengantar tentang Perjalanan dan Persoalannya), Dewan Kesenian Sulawesi Selatan, Makassar.

Taufan Hidjaz, 2004: Terbentuknya Citra dalam Konteks Suasana Ruang dalam Jurnal Dimensi Interior, Jurusan Desain Interior Fakultas Seni dan Desain Universitas Keristen Petra, Surabaya

Wong, Wucius, Beberapa Asas Merancang Dwimatra, Penerbit ITB Bandung, 1986

http://astudioarchitect.com/2009/08/diskusitentang-ruang-dalam-ruangangan.html. 